\title{
Post Solution Posing dengan Cooperative Tipe Berkirim Salam dan Soal terhadap Kemampuan Pemecahan Masalah Matematis
}

\author{
Sekarjati Syahidah Yaumil ${ }^{1}$, Yuyu Yuhana ${ }^{2}$, Isna Rafianti ${ }^{3, *}$ \\ 1,2,3 Universitas Sultan Ageng Tirtayasa \\ *isnarafianti@untirta.ac.id
}

\begin{tabular}{|l|l|l|}
\hline Received : $10-4-2020$ & Revised: $11-4-2020$ & Accepted: $11-4-2020$ \\
\hline
\end{tabular}

\begin{abstract}
ABSTRAK
Tujuan utama penelitian ini adalah untuk mengetahui perbandingan model pembelajaran problem posing tipe post solution posing dengan model pembelajaran cooperative tipe berkirim salam dan soal terhadap kemampuan pemecahan masalah matematis siswa. Penelitian menggunakan metode pre eksperimental design dengan desain penelitian berbentuk matching pretestt-posttest comparison group design. Populasi dalam penelitian ini adalah siswa kelas VIII SMPN 5 Cilegon. Pengambilan sampel menggunakan teknik purposive sampling sehingga diperoleh dua kelas eksperimen. Metode penelitian ini melibatkan dua kelas eksperimen dengan dua perlakuan berbeda yakni kelas eksperimen 1 menggunakan model pembelajaran problem posing tipe post solution posing dan kelas eksperimen 2 menggunakan model pembelajaran cooperative tipe berkirim salam dan soal. Instrumen yang digunakan yakni tes kemampuan pemecahan masalah matematis. Hasil penelitian menyimpulkan bahwa: (1) Peningkatan kemampuan pemecahan masalah matematis siswa yang mendapatkan model pembelajaran problem posing tipe post solution posing lebih baik daripada siswa yang mendapatkan model pembelajaran cooperative tipe berkirim salam dan soal; (2) Pencapaian kemampuan pemecahan masalah matematis siswa yang mendapatkan model pembelajaran problem posing tipe post solution posing lebih baik daripada siswa yang mendapatkan model pembelajaran cooperative tipe berkirim salam dan soal.
\end{abstract}

Kata Kunci : Post Solution Posing, Cooperative tipe Berkirim Salam dan Soal, Kemampuan Pemecahan Masalah Matematis.

\begin{abstract}
The main purpose of this research is to know the comparison of learning model problem posing type post solution posing with cooperative type model type send greeting and problem to student problem solving ability of mathematics. The study used pre-experimental design with research design in the form of matching pretest-posttest comparison group design. The population in this study are students of class VIII SMPN 5 Cilegon. Sampling using purposive sampling technique to obtain two experimental class. This research method involves two experimental classes with two different treatment ie experiment class 1 using model of problem posing problem of post solution posing type and experiment class 2 using cooperative learning model type sends regards and questions. The instrument used is the test of mathematical problem solving ability. The result of this research concludes that: (1) Improvement of mathematical problem solving ability of students who get model of problem posing problem of post solution posing type is better than students who get cooperative learning model type sends regards and questions; (2) Achievement of mathematical problem solving ability of students who get model of problem posing problem of post solution posing type is better than students who get cooperative learning model type sends regards and questions
\end{abstract}

Keywords: Problem Posing Learning Model of Post Solution Posing Types, Cooperative Learning Model of Greeting Sending And Question Type, Mathematical Problem Solving Ability. 


\section{PENDAHULUAN}

Matematika merupakan pelajaran yang sudah tidak asing lagi karena keberadaannya paling sering dipelajari di sekolah-sekolah, mulai dari jenjang pendidikan sekolah kanak-kanak, sekolah menengah, bahkan hingga ke jenjang yang lebih tinggi lagi (Maskur et all, 2020). Cockroft (Hamzah, 2009: 108) mengemukakan mengapa matematika diajarkan. Hal ini disebabkan matematika sangat dibutuhkan dan berguna bagi kehidupan sehari-hari, bagi sains, perdagangan dan industri, dan karena matematika itu menyediakan suatu daya, alat komunikasi, yang singkat dan tidak ambigius serta berfungsi sebagai alat untuk mendeskripsikan dan memprediksi. Seseorang akan merasa mudah memecahkan masalah dengan bantuan matematika, karena ilmu matematika memberikan kebenaran berdasarkan alasan logis dan sistematis. Pendapat tersebut menyatakan bahwa matematika adalah pelajaran yang penting untuk dipelajari.

Menurut Dhurori (2010: 17) kemampuan memecahkan masalah menjadi salah satu tujuan utama dari belajar matematika di antara tujuan yang lain. Hal tersebut dikarenakan (Sumardyono, 2007: 6) matematika merupakan pengetahuan yang logis, sistematis, berpola, artifisial, abstrak, dan yang tak kalah penting menghendaki justifikasi atau pembuktian. Sifat-sifat matematika ini menuntut pembelajar menggunakan kemampuankemampuan dasar dalam pemecahan masalah, seperti berpikir logis, berpikir strategik. Selain itu secara timbal balik maka dengan mempelajari matematika, siswa terasah kemampuan dalam memecahkan masalah. Hal ini dikarenakan strategi dalam pemecahan masalah matematika bersifat "universal" sesuai sifat matematika sebagai bahasa yang universal (artifisial, simbolik). Pendapat lain oleh Dhurori (2010: 17) yang menyatakan bahwa hal ini juga terdapat dalam Standar Kompetensi dan Kompetensi Dasar dalam lampiran Permendiknas No 22 Tahun 2006 tentang Standar Isi (SI). Dalam SI tersebut salah satu dari lima tujuannya adalah agar siswa mampu memecahkan masalah matematika yang meliputi kemampuan memahami masalah, merancang model matematika, menyelesaikan model dan menafsirkan solusi yang diperoleh. Lebih lanjut Hamzah (2009: 122) mengungkapkan bahwa pada intinya, kemampuan matematis merupakan kemampuan mengenal dan memecahkan masalah. Oleh karena itu, kemampuan pemecahan masalah dianggap sangat penting, maka ini menjadi tujuan umum pembelajaran matematika.

Pandangan mengenai pentingnya pemecahan masalah dalam matematika tidak sejalan dengan tingkat kemampuan pemecahan masalah matematika siswa di Indonesia. Pernyataan oleh Wardhani (2011:1) salah satu indikator yang menunjukkan mutu 
pendidikan matematika di tanah air cenderung masih rendah adalah hasil penilaian internasional tentang prestasi siswa. Survai Trends International Mathematics and Science Study (TIMSS) yang diikuti siswa kelas VIII Indonesia tahun 2011. Penilaian yang dilakukan International Association for the Evaluation of Educational Achievement Study Center Boston College tersebut, diikuti 600.000 siswa dari 63 negara. Untuk bidang Matematika, Indonesia berada di urutan ke-38 dengan skor 386 dari 42 negara yang siswanya dites. Skor Indonesia ini turun 11 poin dari penilaian tahun 2007 (Napitupulu, 2012: 1). Padahal, dalam studi TIMSS soal- soal matematika yang digunakan diidentifikasi dalam dimensi kognitif, yakni pemecahan masalah merupakan fokus utama yang muncul dalam soal-soal tes terkait dengan hampir semua topik dalam tiap domain konten (Wardhani, 2011: 47). Demikian pula laporan TIMSS menunjukkan bahwa pembelajaran yang lebih menekankan pada aktivitas penalaran dan pemecahan masalah seperti di Jepang dan Korea mampu menghasilkan siswa berprestasi tinggi dalam matematika (Anggriani \& Septian, 2019). Hal tersebut membuktikan bahwa tingkat kemampuan pemecahan masalah matematika di Indonesia masih rendah.

Usaha-usaha dalam meningkatkan pembelajaran matematika juga harus mempertimbangkan mutu pembelajaran didalamnya. Salah satu saran dari pakar pendidikan matematika, untuk meningkatkan mutu pembelajaran matematika adalah dengan menekankan pengembangan kemampuan siswa dalam pembentukan soal (problem posing) (Inayah, Septian, \& Suwarman, 2020). Karena dengan membentuk soal merupakan inti kegiatan matematis dan merupakan komponen penting dalam kurikulum matematika (Englis dalam Surtini, 2003: 8). Juga seperti yang dikemukakan oleh NCTM yakni "Students should be given opportunities to formulate problems from given situations and create new problems by modifying the conditions of a given problem" yang berarti siswa harus diberikan kesempatan untuk merumuskan masalah dari situasi yang diberikan dan menciptakan masalah baru dengan memodifikasi kondisi dari soal yang diberikan (Silver dan Cai, 1996: 521). Sebenarnya sudah sejak lama para ahli pendidikan matematika menunjukan bahwa pembentukan atau pengajuan soal (problem posing) merupakan bagian yang penting dalam pengalaman matematis siswa dan menyarankan agar dalam pembelajaran matematika ditekankan kegiatan pembentukan soal (Silver, et.al., dalam Surtini, 2003: 8)

Meminjam pendapat Bruner (Trianto, 2009: 7), bahwa berusaha sendiri untuk mencari pemecahan masalah serta pengetahuan yang menyertainya, menghasilkan pengetahuan yang benar- benar bermakna. Suatu konsekuensi logis, karena dengan 
berusaha mencari pemecahan masalah secara mandiri akan memberikan suatu pengalaman konkret, dengan pengalaman tersebut dapat digunakan pula memecahkan masalah-masalah serupa, karena pengalaman itu memberikan makna tersendiri bagi peserta didik.

Berdasarkan paparan di atas, guru dianjurkan untuk menggunakan suatu inovasi yang menarik mengiringi perubahan dalam pembelajaran yang diterapkan dalam suatu model pembelajaran (Septian \& Rizkiandi, 2017). Pendidikan yang berkualitas dapat ditingkatkan melalui melatih pemikiran menggunakan model pembelajaran yang tepat (Maskur et all, 2020). Trianto (2009:10) mengungkapkan bahwa model pembelajaran atau lebih tepat disebut praktik belajar diartikan sebagai suatu inovasi pembelajaran yang dirancang untuk membantu peserta didik memahami teori/konsep-konsep melalui pengalaman belajar praktik-empiris. Model belajar yang diharapkan dapat membantu meningkatkan belajar pemecahan masalah siswa salah satunya adalah dengan menerapkan model pembelajaran berbasis "pengajuan masalah". Dalam hal ini, terdapat dua model pembelajaran yang menggunakan konsep "pengajuan masalah" sebagai cara untuk meningkatkan belajar pemecahan masalah siswa, yakni model pembelajaran problem posing tipe post-solution posing serta model pembelajaran cooperative tipe berkirim salam dan soal. Pada penelitian lain seperti yang dilakukan Khasanah (2016) yang berjudul "Efektivitas model pembelajaran problem posing tipe post solution posing terhadap minat dan hasil belajar peserta didik pada materi matriks Kelas X di Madrasah Aliyah Negeri 1 Semarang Tahun pelajaran 2015/2016" dan Nurhamidah (2014) yang berjudul "Pengaruh penerapan model pembelajaran cooperative teknik berkirim salam dan soal terhadap kemampuan pemecahan masalah matematika siswa SMP Negeri 1 Tebing Tanjung Balai Karimun" hasilnya menunjukkan bahwa kedua tipe pada model pembelajaran tersebut memiliki efektif dan berpengaruh secara positif dalam meningkatkan minat belajar dan kemampuan matematis siswa. Sedangkan penelitian ini ingin melihat perbandingan kedua tipe model pembelajaran tersebut untuk mengetahui tipe model pembelajaran manakah yang lebih baik dalam meningkatkan kemampuan pemecahan masalah matematis.

Model pembelajaran problem posing merupakan model pembelajaran yang mengharuskan siswa menyusun pertanyaan sendiri atau mengajukan suatu masalah yang dikonstruksinya sendiri. Terdapat beberapa tipe pendekatan pembelajaran mengenai problem posing, salah satunya adalah metode problem posing tipe post solution posing yaitu jika seorang siswa memodifikasi tujuan atau kondisi soal yang sudah 
diselesaikan untuk membuat soal yang baru yang sejenis. Tipe jenis ini diharapkan akan membuat peserta didik terbiasa dengan penyelesaian-penyelesaian soal yang beragam.

Model pembelajaran lainnya yang menggunakan "pengajuan masalah" sebagai sasaran pembelajaran adalah dengan menerapkan model pembelajaran cooperative tipe berkirim salam dan soal. Model pembelajaran ini mampu memberikan kesempatan kepada siswa untuk melatih pengetahuan dan keterampilan mereka. Siswa membuat pertanyaan beserta jawaban secara berkelompok yang kemudian pertanyaan tersebut akan diajukan kepada kelompok lain dengan terlebih dahulu memberikan salam kelompok berupa yel- yel. Hal tersebut diharapkan dapat menghidupkan suasana kelas dan membangkitkan keaktifan siswa, sehingga terdorong untuk belajar dan menjawab pertanyaan yang diajukan teman sekelasnya.

Dari penjabaran singkat tesebut, kesamaan dari dua model pembelajaran secara umum yakni model pembelajaran Problem posing tipe post-solution posing serta model pembelajaran cooperative tipe berkirim salam dan soal secara garis besar adalah model pembelajaran yang menggunakan konsep "pengajuan masalah". Dalam pembelajaran tersebut, siswa dilibatkan secara aktif dalam proses pengajuan serta pembuatan masalah. Belum selesai hanya membuat pengajuan masalah, siswa juga diajak berpikir bagaimana menyelesaikan masalah tersebut. Beberapa hasil penelitian telah menunjukkan manfaat dari belajar pengajuan masalah tersebut, antara lain hasil penelitian Silver dan Cai (1996: 521) menyatakan bahwa siswa yang dapat merumuskan soal matematis memiliki kemampuan pemecahan masalah yang lebih tinggi daripada siswa yang tidak dapat membuat soal. Hasil penelitian lain yang dilakukan oleh Hashimoto (dalam Silver dan Cai, 1996: 522) menyebutkan bahwa pembelajaran dengan pengajuan masalah (problem posing) menimbulkan dampak positif terhadap kemampuan siswa dalam pemecahan masalah (problem solving).

Pelaksanaan pembelajaran pada problem posing tipe post solution posing dan cooperative tipe berkirim salam dan soal mamiliki tahapan yang hampir serupa, yakni: pembelajaran materi, bimbingan dalam pengajuan masalah secara kelompok serta menyelesaikan masalah yang diajukannya sendiri, menukarkan masalah dengan teman sekelas, mengembangkan dan menyajikan hasil karya, serta menganalisis dan mengevaluasi proses pemecahan masalah. Dalam penerapannya, siswa akan lebih banyak dilibatkan dalam proses pembelajaran, berdiskusi dengan teman, berlatih mengajukan dan menyelesaikan soal, serta mempresentasikan hasil pembelajaran di kelas. 
Pelaksanaan pembelajaran pada kedua model ini hampir serupa, namun terdapat perbedaan dalam konsep pengajuan masalahnya. Model pembelajaran problem posing tipe post solution posing dalam pengajuan masalahnya didasarkan atas masalah yang telah ditemukan solusinya. Sedangkan model pembelajaran cooperative tipe berkirim salam dan soal dalam pengajuan masalahnya tidak memiliki ketentuan apapun, siswa hanya diarahkan untuk mengajukan masalah berdasarkan pengetahuan dan pengalaman yang dimilikinya dalam pembelajaran materi. Atas dasar inilah, penulis tertarik untuk membandingkan kedua model pembelajaran yang serupa dalam pembelajarannya, namun berbeda dalam konsep pengajuan masalah.

\section{METODE PENELITIAN}

Metode penelitian yang digunakan dalam penelitian ini adalah metode preeksperimental design, pengukuran dilakukan sebelum (pretes) dan sesudah (postes) diberikannya perlakuan untuk kemudian dibandingkan hasilnya antara pengukuran awal dan akhir pada masing-masing kelas sedangkan desain penelitian yang digunakan adalah desain matching pretes-postes comparison group design. Penelitian ini dilaksanakan di SMPN 5 Cilegon. Pengambilan sampel dalam penelitian ini menggunakan teknik Purposive Sampling. Dua kelas yang peneliti ambil dari SMP Negeri 5 Cilegon adalah kelas VIII B dan kelas VIII D.

Instrumen yang digunakan yakni instrumen tes yakni lima butir soal uraian, bertujuan untuk mengetahui kemampuan pemecahan masalah matematis siswa. Dua kelas yang terpilih, kemudian diberikan tes awal untuk mengetahui adakah perbedaan kemampuan awal pemecahan masalah matematis siswa diantara kedua kelas tersebut. Setelah itu diberikan perlakuan, kemudian pemberian tes akhir untuk mengetahui keadaan setelah pemberian perlakuan. Dua kelas tersebut akan sama- sama diberikan tes awal dan tes akhir dengan instrumen soal yang sama pada setiap kelas.

Data yang dianalisis yaitu data kemampuan pemecahan masalah matematis berupa data pretes, postes dan data gain dengan menggunakan analisis data statistik deskriptif dan inferensial. Statistik deskriptif adalah statistik yang digunakan untuk menganalisis data dengan cara mendeskripsikan atau menggambarkan data yang telah terkumpul sebagaimana adanya tanpa bermaksud membuat kesimpulan yang berlaku untuk umum atau generalisasi (Sugiyono, 2010: 169). Sedangkan statistik inferensial adalah statistik yang digunakan untuk menganalisis data sampel, dan hasilnya akan digeneralisasikan (diinferensikan) untuk populasi di mana sampel diambil (Sugiyono, 2010: 23). Tahap 
analisis yang digunakan adalah uji prasyarat yang meliputi uji normalitas dan uji homogenitas, selanjutnya adalah uji parametrik yang meliputi uji perbedaan dua rerata, uji t dan uji t'. Selain itu menggunakan uji non parametrik yaitu uji Mann Whitney jika data tidak berdistribusi normal.

\section{HASIL DAN PEMBAHASAN}

Penelitian ini dilaksanakan di SMP Negeri 5 Cilegon kelas VIII dengan tujuan untuk mengetahui perbedaan kemampuan pemecahan masalah matematis siswa kelas eksperimen 1 yang menggunakan model pembelajaran problem posing tipe post solution posing dengan kelas eksperimen 2 yang menggunakan model pembelajaran cooperative tipe berkirim salam dan soal. Dua kelas yang terpilih, yaitu kelas VIII B sebagai kelas eksperimen 1 dan kelas VIII D sebagai kelas eksperimen 2. Jumlah sampel untuk dalam penelitian ini sebanyak 76 siswa yang terdiri dari 38 siswa kelas eksperimen 1 dan 38 siswa kelas eksperimen 2. Penelitian ini berlangsung selama 8 kali pertemuan yang terdiri dari pretes, postes, dan enam kali pembelajaran. Data yang dikumpulkan dalam penelitian ini adalah hasil nilai tes awal dan tes akhir kemampuan pemecahan masalah matematis siswa.

Data tes berupa kemampuan pemecahan masalah matematis diperoleh dari pretes, postes, dan $n$-gain. Soal yang diberikan pada saat pretest sama dengan soal yang diberikan pada saat posttest. Sedangkan n-gain diperoleh untuk melihat peningkatan kemampuan pemecahan masalah matematis siswa yang terjadi pada kelas eksperimen 1 dan kelas eksperimen 2 dengan mencari selisih skor antara pretes dan postes kemudian dibandingkan dengan selisih skor maksimum dan pretest pada kelas masing-masing.

Berdasarkan hasil pengolahan data postes dari siswa dengan jumlah masingmasing kelas yakni 38 orang, memiliki nilai rata-rata kelas eksperimen 1 adalah 39,82 dan kelas eksperimen 2 adalah 27,89. Dengan nilai statistik thitung lebih besar dari $t_{\text {tabel }}$ yakni 4,684 > 2,288. Hal ini menunjukkan bahwa pencapaian kemampuan pemecahan masalah matematika siswa yang mendapatkan pembelajaran matematika dengan model problem posing tipe post solution posing lebih baik daripada pencapaian kemampuan pemecahan masalah matematika siswa yang mendapatkan model pembelajaran cooperative tipe berkirim salam dan soal.

Peningkatan kemampuan pemecahan masalah matematis siswa pada kelas eksperimen 1 dan kelas eksperimen 2 diukur dengan melakukan perhitungan $n$-gain. Analisis data $n$-gain dilakukan dengan cara yang sama dengan analisis data tes yang telah 
dipaparkan sebelumnya. Setiap data n-gain diuji dengan menggunakan statistika deskriptif dan statistika inferensial. Untuk mengetahui perbedaan peningkatan kemampuan pemecahan masalah matematis siswa maka dilakukan uji normalitas, uji homogenitas dan uji hipotesis (uji satu pihak).

Berdasarkan hasil pengolahan data gain, diperoleh hasil analisis statistika deskriptif bahwa nilai rata-rata gain kelas eksperimen 1 adalah 0,46 dan kelas eksperimen 2 adalah 0,25. Dari hasil pengujian diperoleh $t_{\text {hitung }}=6,251$ dan $t_{\text {tabel }}=1,993$, karena diketahui $t_{\text {hitung }}>\mathrm{t}_{\text {tabel}}$, maka Ho ditolak, hal ini menunjukkan bahwa peningkatan kemampuan pemecahan masalah matematika siswa yang mendapatkan pembelajaran matematika dengan model problem posing tipe post solution posing lebih baik daripada peningkatan kemampuan pemecahan masalah matematika siswa yang mendapatkan model pembelajaran cooperative tipe berkirim salam dan soal.

Untuk menganalisis setiap indikator kemampuan pemecahan masalah matematis di kelas eksperimen 1 dan kelas eksperimen 2 yaitu dengan menghitung persentase yang diperoleh di setiap indikator ditinjau dari keseluruhan siswa agar dapat dibandingkan perolehan antara kedua kelas tersebut. Hasil analisis setiap indikator disajikan dalam table berikut.

Tabel 1. Persentase data postes per indikator kelas eksperimen 1 dan kelas eksperimen 2

\begin{tabular}{lcc}
\hline Indikator & Eksp 1 & Eksp 2 \\
\hline $\begin{array}{l}\text { Mengidentifikasi data diketahui, data ditanyakan, } \\
\text { kecukupan data untuk pemecahan masalah }\end{array}$ & $69,65 \%$ & $52,89 \%$ \\
\hline Mengidentifikasi strategi yang dapat ditempuh & $64,47 \%$ & $27,37 \%$ \\
\hline Menyelesaikan model matematika disertai alasan & $61,40 \%$ & $49,65 \%$ \\
\hline Memeriksa kebenaran solusi yang diperoleh & $23,68 \%$ & $7,37 \%$ \\
\hline
\end{tabular}

Berdasarkan Tabel 1, terlihat bahwa persentase tertinggi pada kedua kelas dicapai oleh indikator 1 yakni mengidentifikasi data diketahui, data ditanyakan dan kecukupan data. Sedangkan persentase terendah pada kedua kelas terdapat pada indikator 4 yakni memeriksa kebenaran solusi yang diperoleh. Hal ini dikarenakan siswa belum terbiasa menggunakan tahapan pemecahan masalah matematika pada penyelesaian masalah yang dihadapinya. Sehingga mereka lebih mampu melaksanakan tahapan pada indikator 1 dan indikator 3 karena terbiasa menyelesaikan masalah dengan hanya menggunakan tahap mengidentifikasi data dan menyelesaikannya, dan juga sebagian besar siswa hanya berfokus menyelesaikan masalah tanpa memeriksa kebenaran jawabannya kembali. 
Salah satu faktor penyebab terdapat perbedaan pencapaian kemampuan matematis siswa tersebut adalah dikarenakan kondisi kelas pada saat pembelajaran berlangsung. Pada dasarnya, kelas ekperimen 1 dan kelas ekperimen 2 memiliki siswa dengan karakteristik yang sama, yakni sangat aktif dan sulit berkonsentrasi ketika pelajaran berlangsung. Hal tersebut cukup mampu diatasi oleh peneliti, hanya saja dalam model pembelajaran cooperative tipe berkirim salam dan soal terdapat tahapan yang mengharuskan siswa melakukan salam antar kelompok (yel-yel) untuk menaikan motivasi belajar siswa. Ditengah pelajaran yang sudah cukup kondusif, siswa kelas eksperimen 2 harus menyanyikan yel-yel dengan sangat antusias, sehingga keadaan kelas menjadi gaduh dan kembali sulit untuk dikendalikan. Akibatnya proses pembelajaran tertunda dalam beberapa menit untuk kembali mengkondusifkan kondisi kelas. Tertundanya proses pembelajaran di tengah-tengah tersebut mengakibatkan kurang efektifnya pembelajaran yang sedang berlangsung di kelas eksperimen 2, waktu yang dipergunakan untuk proses pembelajaran semakin sedikit, dan pembelajaran menjadi agak terburu-buru dan tidak mencapai hasil yang maksimal. Diakhir pembelajaran, siswa yang terburu-buru menjadi lebih memprioritaskan terselesaikannya tugas daripada kerjasama kelompok, akibatnya beberapa orang didalam kelompok terabaikan dan tidak ikut menyelesaikan tugas kelompoknya.

\section{KESIMPULAN}

Berdasarkan hasil pengolahan dan analisis data dari hasil penelitian yang dilakukan di SMPN 5 Cilegon pada siswa kelas VIII, maka diperoleh kesimpulan bahwa pencapaian kemampuan pemecahan masalah matematika siswa yang mendapatkan pembelajaran matematika dengan model problem posing tipe post solution posing lebih baik daripada pencapaian kemampuan pemecahan masalah matematika siswa yang mendapatkan model pembelajaran cooperative tipe berkirim salam dan soal, serta peningkatan kemampuan pemecahan masalah matematika siswa yang mendapatkan pembelajaran matematika dengan model problem posing tipe post solution posing lebih baik daripada peningkatan kemampuan pemecahan masalah matematika siswa yang mendapatkan model pembelajaran cooperative tipe berkirim salam dan soal. 


\section{REFERENSI}

Anggriani, A., \& Septian, A. (2019). Peningkatan Kemampuan Komunikasi Matematis dan Kebiasaan Berpikir Siswa Melalui Model Pembelajaran IMPROVE. IndoMath: Indonesia Mathematics Education, 2(2), 105-116. https://doi.org/10.30738/indomath.v2i2.4550

Dhurori,A \& Markaban. (2010). Pembelajaran Kemampuan Pemecahan Masalah dalam Kajian Aljabar di SMP. Jakarta: Kementerian Pendidikan Nasional PPPPTK.

Hamzah, B \& Kuadrat, M. (2009). Mengelola Kecerdasan dalam Pembelajaran. Jakarta: Bumi Aksara.

Inayah, S., Septian, A., \& Suwarman, R. F. (2020). Student Procedural Fluency in Numerical Method Subjects. Desimal: Jurnal Matematika, 3(1), 53-64. https://doi.org/10.24042/djm.v3i1.5316

Khuswatun, U. (2016). Efektifitas Model Pembelajaran Problem Posing tipe Post Solution Posing terhadap Minat dan Hasil Belajar Peserta Didik pada Materi Matriks Kelas X di Madrasah Aliyah Negeri 1 Semarang Tahun pelajaran 2015/2016. Fakultas Sains dan Teknologi. Semarang: Universitas Islam Negeri Walisongo.

Napitupulu. (2012). Prestasi Sains dan Matematika Indonesia Menurun. Jakarta. [online] Tersedia di:edukasi.compas.com (diakses 21 Februari 2017).

Maskur, R., Sumarno, Rahmawati, Y., Pradana, K., Syazali, M., Septian, A., \& Palupi, E. K. (2020). The effectiveness of problem based learning and aptitude treatment interaction in improving mathematical creative thinking skills on curriculum 2013. European Journal of Educational Research, 9(1), 375-383. https://doi.org/10.12973/eu-jer.9.1.375

Nurhamidah. (2014). Pengaruh Penerapan Model Pembelajaran Kooperatif Teknik Berkirim Salam dan Soal Terhadap Kemampuan Pemecahan Masalah Matematika Siswa SMP Negeri 1 Tebing Tanjung Balai Karimun. Fakultas Tarbiyah dan Keguruan. Pekanbaru: Universitas Islam Negeri Sultan Syarif Kasim Riau.

Septian, A., \& Rizkiandi, R. (2017). Penerapan Model Problem Based Learning (PBL) terhadap Peningkatan Kemampuan Berpikir Kreatif Matematis Siswa. PRISMA, 6(1). https://doi.org/10.35194/jp.v6i1.22

Septian, A. (2017). Penerapan Geogebra untuk Meningkatkan Kemampuan Pemecahan Masalah Matematis Mahasiswa Program Studi Pendidikan Matematika Universitas Suryakancana. PRISMA, 6(2). https://doi.org/10.35194/jp.v6i2.212

Silver, E.A. \& Cai, J. (1996). "An Analisis of Arithmetic Problem posing by Middle School Students", Journal for Research in Mathematics Education, 27, No. 5.

Sugiyono. (2010). Metode Penelitian Pendidikan. Bandung: CV. Alfabeta

Sumardyono. (2007). Pengertian Dasar Poblem Solving. Jakarta: PPPPTK. [online] www.docplayer.info (diakses 21 Februari 2017).

Surtini, S, dkk. (2003). Implementasi Problem posing pada Pembelajaran Operasi Hitung Bilangan Cacah Siswa Kelas IV SD di Salatiga. Salatiga: Lembaga Penelitian Universitas Terbuka Salatiga.

Trianto. (2009). Mendesain Model Pembelajaran Inovatif-Progresif. Jakarta: Kencana Prenada Media Group.

Wardhani, S. (2010). Pembelajaran Kemampuan Pemecahan Masalah Matematika. Jakarta: Kementerian Pendidikan Nasional PPPPTK Matematika.

Wardhani, S. (2011). Instrumen Penelitian Hasil Belajar Matematika SMP: Belajar dari PISA dan TIMSS. Jakarta: Kementerian Pendidikan Nasional PPPPTK Matematika. 